\title{
METHODOLOGY OF TEACHING LABOUR LAW VOCABULARY IN THE ACADEMIC SUBJECT OF LEGAL ENGLISH
}

\author{
Elena Prendjova ${ }^{1}$
}

DOI: https://doi.org/10.31410/ERAZ.2019.95

\begin{abstract}
Studying the subject of Legal English is mandatory for the students of Law. Few of the important units of the subject of Legal English are the unit of Labour Law and the unit of Employment Rights. The emphasis of the units is a brief introduction to the nature of these types of law and a presentation, explanation, translation and practice of the relevant vocabulary. The paper ,Methodology of Teaching the Labour Law Vocabulary in the Academic Subject of Legal English" deals with the various teaching methods used in the English for Specific Purposes classroom when teaching the vocabulary relevant to the subject matter of Labour Law and Employment Rights. The stress is on the types of exercises (vocabulary, reading and speaking), as well as the methods of conducting them in the classroom.
\end{abstract}

Keywords: Legal English, Labor Law, Employment Rights, methodology of teaching English for Specific Purposes.

\section{INTRODUCTION}

$\mathrm{V}$

ocabulary constitutes the major part of English for Specific Purposes (ESP) learning; thus, it is of great importance for Ss to build a consistent body of technical terms specific to their field of study. Indeed, vocabulary is but the basis Ss are required for their future careers, as well as the basis on which they shall build their ongoing field studies. As Mohan and van Naerssen indicate, ,knowledge of the vocabulary of a subject area helps learners understand better their area of study because it broadens their knowledge" (Chirobocea, 2018). In addition, the best way to be successful in vocabulary acquisition is, as Woodward-Kron suggests, for Students (Ss) to be able to engage their specialist language with their disciplinary knowledge (Chirobocea, 2018).

Hence, teaching vocabulary is crucial for the ESP courses, since the course is aimed to teach Ss manage in English in their own academic filed, rather than in some general social situation, i.e. to enable Ss to communicate within their professional environment, as well as to use resources, such as reading academic journals in English, using professional web-sites in English, etc.; and, not to mention to write their own academic papers in English. In order to be able to do all that, Ss should learn more than the aspects of the meaning of the words and the phrases (synonyms, antonyms, translation, definition and explanation), yet, also, their lexical form, such as spelling, pronunciation, part of speech; collocations (the possible combinations of the words and their usage in phrases); word formation (prefixes, suffixes and compounds), etc.

Unfortunately, Ss are not very keen on studying new vocabulary, so it is quite a challenge for the lecturer (L) to teach it and to motivate Ss to learn it, too. Similarly, Ss may find the process of learning new vocabulary monotonous, because it requires time, patience and revision, and in this instant technological era, learning vocabulary comes down to looking up the meaning of the new words on the cell phone applications or simply googling them. 
Due to those facts, Ls who teach ESP courses, on the one hand, should be, at least, familiar with the core vocabulary of the field of study; and, on the other, should use vocabulary teaching methods that are effective in long-term learning. The paper's aim is to offer a methodological approach to teaching vocabulary of a certain narrow field of Legal English, in this case, Labor Law. Moreover, the paper presents an example of methodology in teaching the unit of Labor Law alongside the unit of Employment Rights and is based on author's teaching experience.

\section{LEGAL ENGLISH VOCABULARY}

Legal English, and ESP in general, is content-and-language integrated learning that, in theory, requires two lecturers: a language teacher and a subject matter teacher. However, in practice, it is always single English as a Second Language (ESL) lecturer with the knowledge of both language and Law. This indicates that the core of the Legal English vocabulary is restricted to merely the basic legal vocabulary, yet to the high-frequency words with specialized meanings. This perfectly adds up to the fact that Legal English is studied in the first year of the first cycle of Law studies, which means that Ss are not much familiar with the subject matter, that is to say, that they are still at the point of introduction into the field of study. Thus, teaching Legal English vocabulary indicates that the $\mathrm{L}$ should be able to introduce to the Ss not only the word/s or the phrase/s, but also their definitions and meanings, i.e. not only the vocabulary itself, but also the concepts of the subject terminology.

In addition, to teach Legal English vocabulary, a monolingual or a bilingual dictionary of law is needed. Also, apart from the standard General English (GE) vocabulary teaching methods, the L should use teaching methods that will not only teach Ss new vocabulary, but also make them use their previously acquired knowledge of the other academic subjects.

Furthermore, among the various strategies for discovering the meaning of the unknown words without using dictionaries is the strategy of guessing the meaning from the context. This is, actually, the first stage of the vocabulary teaching method - presenting the vocabulary. Legal terms are presented in a context-relevant short text and in the glossary related to the text. The new vocabulary can be presented with its synonyms or antonyms, or by matching the new terms to their definitions, explanations, synonyms or antonyms, abbreviation, first language (L1) equivalent, their collocation, etc.

Fortunately, some of the terminology is already known to the Ss. In that case, the L should check if the Ss understand the technical vocabulary and if they are able to use it properly and actively, which leads to the second stage of vocabulary teaching - practice. Follow-up exercises enable Ss use the new vocabulary in a suitable context and the context is indeed crucial for the process of learning new vocabulary. These follow-up exercises can be multiple choice or gap-filling. The former instructs Ss to choose the correct or most suitable word, and the latter instructs Ss to fill in the gap with the most suitable term. Finally, there are the speaking-oriented exercises that encourage Ss to actively practice the usage of the new, as well as the already established vocabulary.

Apart from the context, another factor of effective learning is the use of collocations. Namely, technical vocabulary combines more words as collocations than GE vocabulary. This makes ESP learning more complex, which requires more effort in combing the words and phrases correctly. L should assist Ss become familiar with the collocations, as well as become more aware 
of the words that go together. In the case of Legal English, special emphasis, too, should be put on the Latin terms and abbreviations frequently used in legal forms and contracts.

Of course, one should always have in mind John Morgan's and Mario Rinvolucri's opinion, who presented their views in their study Vocabulary (OUP Oxford, 2004), that „,new words are not learned mechanically, but associatively" (Xhaferi, 2009). This, of course, adds up to the greater context Ss face with their studies - the greater picture of their academic field assembled by all the other academic courses. Thus, the main role of the ESP L should be to enable Ss, firstly, understand correctly the technical vocabulary, and, secondly, use it independently and appropriately. Hence, the L should adjust their vocabulary teaching methods accordingly. Certainly, whatever method the $\mathrm{L}$ decides to use, it should be democratic, engaging, student-centered and participatory.

\section{TEACHING LABOUR LAW AND EMPLOYMENT RIGHTS VOCABULARY}

The unit of Labor Law is tightly connected to the unit of Employment Rights, so we have decided to teach them together as a single unit in two sections. The materials we use in class relevant for these units are extracts from the textbooks: Speaking Legal English by L. A. Borisova (Labor Law unit) and Практическйи курс основного иностранного языка англйискйи язык. Профессиональный курс юридическйи. Юнита 4. by S. V. Smirnova (Employment Rights unit).

The textbooks provide various vocabulary-oriented exercises. The warm-up exercises are but an introduction to the topic of Labor Law. For example, Borisova introduces the Labor Law vocabulary by eliciting meaning from a context in a gap-filling exercise. She introduces a list of the core vocabulary relevant to the topic:

- To employ (v),

- To be permanently/ temporarily employed (phr.),

- Full-time employee (n),

- Part-time employee (n),

- Blue-collar (n),

- White-collar (n),

- To recruit (v),

- To dismiss (v),

- To make somebody redundant (phr.),

- Employer (n),

- Employment opportunities (coll.),

- Employment contract (coll.),

- Employment conditions (coll.),

- Unemployment rate (coll.),

- Fringe benefits (coll.),

- Child benefit (coll.),

- Unemployment benefit (coll.),

- Invalidity benefit (coll.),

- Sickness benefit (coll.),

- Maternity benefit (coll.),

- Social security (n),

- Insurance (n),

- Trade union (n). 
Before doing the exercise, Ss with the help of the L define, explain and translate the words and the phrases. This can be done with vocabulary memo cards created by the L. The memo cards can be blue-tacked on the board and Ss might be encouraged to match the words and phrases with their definitions, or just match the parts of the collocations. In addition, Ss may group them in different groups, for example, in nouns/noun phrases and verbs, or positive and negative notions, etc. Finally, Ss can just be invited to discuss the meanings of the new words/phrases.

After they acquire their exact meaning, Ss do the exercise individually, in pairs or in small groups of 3-4. The exercise can be checked as a quiz. The L divides the whole class in two bigger groups and chooses a moderator. Each $\mathrm{S}$ of each group reads a sentence from the exercise, for example: „The trade union threatened strike action if its demands were not met”. - the underlined words being the ones that should be filled in (Borisova, 2007). Ss read alternately. The role of the moderator is to check whether the answers are correct, sound the buzzer if they are not, invite a $\mathrm{S}$ from the other group to provide another answer, and, at the end, give a point for each correct answer. The group with the greatest number of correct points is the winner of the quiz.

The gap-filling exercise is followed by a discussion exercise that encourages Ss to speak in the second language (L2), as well as practice the newly acquired vocabulary. The questions such as: „How long should vacations last?; Should children be allowed to work?; What problems may women face as far as employment is concerned?; What should the retirement age be?"; etc. (Borisova, 2007) are deeply challenging - they not only boost Ss' creativity and thinking, but also inspire them to use their overall legal knowledge. L should make sure all Ss are involved in the discussion and state their own personal opinion. They should mind Ss' pronunciation, grammar in use and sentence structure, not only their usage of relevant vocabulary.

The successive exercise is a reading exercise on the topic of employment laws in Japan. L encourages Ss read the text aloud, explain the new words or revise the old ones, as well as discuss the text and the topic in comparison to the employment laws in their own country. Two next texts are introduced - one on employment rights according to the English legislation and the other titled „EC employment law”, both from the Smirnova textbook. This combination of texts of the two different textbooks enables Ss not only revise vocabulary, but also expand it. The method of work on the other two texts is similar to the method of presenting the first text. Ss are encouraged to work on the vocabulary individually, in pairs and in small groups under the guidance and with the help of the L. In my personal experience, handmade memo cards have been always the best choice to present new vocabulary, so we do recommend using them in this exercise, too. These reading exercises may be concluded with a debate on the topic of „European Commission (EC) employment laws vs. employment laws in Japan - strengths and weaknesses" with possible solutions of improving the laws' negative sides.

The session may end with homework (HW) on the topic of „How to reduce unemployment rate”. The HW should be done individually, in pairs or in small groups as a project presentation and presented in the revision class. L2 to L1 translation can be offered as a useful concluding revision exercise. L chooses the most important extracts from the texts. $\mathrm{L}$ and Ss work on the first extract together. Afterwards, L divides the whole class into groups of 3-4 and assigns the other extracts to the groups to work on. This time, Ss work without the help of the L. At the end, they all read and edit the translations together and with the help of the L. Special emphasis is put on the proper translation of the legal terms, yet one should not forget that translations should sound natural and authentic. 


\section{CONCLUSION}

In conclusion, teaching specialized vocabulary is essential to the ESP classroom. Thus, a productive vocabulary learning process is essential. In that sense, vocabulary should be taught in a well-defined context and through various participatory exercises: gap-filling, reading, translation and communicative exercises, since the PPP Approach (Presentation, Practice, and Production) is the best way for vocabulary acquisition. Hence, when teaching vocabulary, Ls should first use the Task-Based Approach to introduce new vocabulary, then the Communicative Approach to practice it. The final goal should be enabling Ss independently and accurately use legal terminology.

\section{REFERENCES}

[1] Borysova, L. A. (2007) Speaking Legal English, Yzdavatel'sko-polyhrafyčeskyj centr, Voronežskoho hosudarstvennoho unyversyteta. pp. 52-54

[2] Smyrnova, S. V. (1998) Praktyčeskjy kurs osnovnoho ynostrannoho jazыka anhljyskjy jazыk. Professyonal'nыj kurs jurydyčeskjy. JUnyta 4. NOU „Sovremennыj Humanytarnыj Ynstytut". pp. 87-89

[3] Semyda, O.V. Teaching ESP Vocabulary, „Nacional'nyj tehničnyj universytet Ukrajiny «Kyjivs'kyj politehničnyj instytut imeni Ihorja Sikors'koho»".

http://www.kamts1.kpi.ua/sites/default/files/files/semyda_teaching.pdf

[4] Chirobocea, O. 2018, "Vocabulary Acquisition in ESP. Perspectives, Strategies and Resources" in Studii şi cercetări filologice. Seria limbi străine aplicate, no. 17/2018, Piteşti, pg. 171-180. (ISSN-L 1583-2236; e-ISSN 2344-4525). https://www.researchgate.net/publication/330324952_Vocabulary_Acquisition_in_ESP_Perspectives_Strategies_and_Resources

[5] Xhaferi, B. (2009) Teaching and learning ESP vocabulary, South East European University (Macedonia). https://dialnet.unirioja.es/descarga/articulo/3410918.pdf 